DOI:10.32703/2415-7422-2020-10-2-339-352

UDC 930.85:929:001

\title{
Vira Okorokova
}

South Ukrainian National Pedagogical University named after K. D. Ushinsky

26, Staroportofrankivska Street, Odesa, Ukraine, 65020

e-mail:veraok888@ukr.net

https://orcid.org/0000-0003-0661-4313

\section{Olha Likhachova}

South Ukrainian National Pedagogical University named after K. D. Ushinsky 26, Staroportofrankivska Street, Odesa, Ukraine, 65020

e-mail: dagazdagaz@ rambler.ru

https://orcid.org/0000-0002-3262-4913

\section{Formation components of technical science in Ukraine in the 60-70s of the XIX century}

Abstract. The article is devoted to the study of the formation of technical science in Ukraine in the second half of the XIXth century. The source of data for the research was found in the articles of the "Journal of the Ministry of Public Education" that was published in the 60-70s of the XIXth century. This historical source explains the chronological boundaries of the research mentioned. The authors draw attention to the formation of technical science as to a complex process that developed from the historical and cultural transformations in the field of scientific research of Ukrainian society back in the days. Paradigmatic shifts in Western European science that penetrated the scientific circles of the Ukrainian social environment contributed to the intensification of scientific and technological progress. It is noted that the latter had a great influence on education which, as shown in the article, became one of the components in the forming process in the field of science and technology.In particular, we are talking about the active work of scientific and technical intelligentsia, which became the driving force in this process, which was expressed in the creation of a theoretical and methodological basis for scientific activities. Based on a wide range of methods derived from the historical research, the progress factors in this scientific field as well as the growth of scientific schools of leading mathematicians, physicists, and other representatives of technical science were discovered. On the basis of the biographical method of analysis the creative way of heads of known scientific schools (V. Ya. Buniakovskyi, I. O. Vyshnehradskyi, M. V. Ostrohradskyi, F. N. Shvedov and others) in line with the trends of the then Ukrainian scientific and technical 
industry. The research points out the importance and invaluable contribution made by scientists for further motivation and actualization of the research in subsequent years. It is emphasized that the emergence of scientific schools and modernization of the technical education system have become the main components in the formation of the scientific and technical elite. It was made through an active scientific activity that contributed to the formation of technical science at the theoretical and methodological levels.

Keywords: Journal of the Ministry of Education; scientific school; scientific and technological progress; technical science

\section{Introduction.}

The history of technical science in Ukraine has a complex mechanism based on the interaction of scientific, technical, theoretical, conceptual, and often paradigmatic studies. Those have been integral to Western European scientific traditions. Ukrainian science still impresses with a well-known constellation of scientists who for many centuries have contributed to the foundation of the modern direction in scientific knowledge. A special place is occupied by the field of natural science, which played a significant role in the formation of technical science in Ukraine. The theoretical design of natural science dates back to the XIXth century.

The specificity of this topic, which simultaneously enhances its relevance, as well as theoretical, and methodological apparatus, is manifested in its source base. The source base consists of the study based on two types of components: the first source covers technical inventions, devices, and research experiments, while the second one is derived from the written sources that contain information about the first type and most importantly reveal the process of forming representatives of a certain scientific elite and science in general. The presented article is the result of research related to the second type.

It should be noted that the source base for this research was gathered from the articles written by prominent scientists, teachers, and public figures of Ukrainian science of the second half of the nineteenth century. Those were published in the "Journal of the Ministry of Education" (hereinafter - "Journal") - the official body of the Ministry of public education. The choice of this periodical was made due for several reasons. Firstly, royal decrees, ministerial orders, and orders made by the Academic Committee of Public Education have been published in the section "Government orders" of this journal. These documents provide an opportunity to assess the state direction in creating a base for technical education. Secondly, the articles in the section of the journal entitled "Criticism and Bibliography", which contained headings such as: "Our educational literature", "Reviews of foreign journals", "Critical and bibliographic notes", "Modern Chronicle" cover the problematic aspects in the process of technical and natural science formation.

The attention is placed on the articles under the heading "Department of Sciences" since the prominent scientist I. I. Mechnykov as well as economist, president of Kyiv 
University, and future Minister of Finance of the Russian Empire M. Kh. Bunhe published their researches in these articles. The works of Mechnykov and Bunhe as well as other prominent scientists reflected new trends and significant steps made in the field of physics, mathematics, chemistry, biology. The fact that world-renowned scientists have been published in this journal indicates the creation of a field dedicated to the scientific research that united the intellectual environment of that time.

In the post-Soviet period, the issues of formation and development of technical education were studied through two main directions. Historians paid attention to the general and regional directions of education development in the XIX century and also touched upon the formation of technical educational institutions. For example, the articles by H. Shevchuk, Ya. Plavutskoi - Lutsenko (Shevchuk, 2011; PlavutskaLutsenko, 2013). The article written by S. Hushchyna considered the formation of private educational institutions in the XIXth - early XXth centuries (Hushchyna, 2007). The questions of the formation of professional education and the generalizing monograph of S. Siropolko are also considered in the research (Siropolko, 2001). The second direction is represented by works that analyzed the history of the formation and development of vocational education in Ukraine. This view on the problem is also reproduced in the article by $\mathrm{O}$. Tovkanets and in the dissertation of M. Honchar (Tovkanets, 2011; Honchar, 2016). Aditionally, in the monograph of I. L. Likarchuk, the historical retrospective of the formation of vocational schools in Ukraine is outlined (Likarchuk, 1999). Nowadays, there is a lack of historical research that would consider the complex question of the relationship and dynamics of science and education in the 60-70s of the XIX century.

Therefore, the purpose of this study is to determine the components of the technical science formation in Ukraine, which consequently created a theoretical and methodological basis for its further development as a separate scientific field of knowledge.

The chronological boundaries of the work cover the period of the 60-70s of the XIXth century. This is the time frame when technical knowledge in the Ukrainian scientific environment formed the basis of technical science.

Tasks:

- to reveal the factors of formation of technical science in the specified period;

- to identify the components of the formation of technical science, in particular, the formation of scientific schools in this field and the modernization of the education system of technical specialties.

\section{Research methods.}

The methodological basis for the study of this problem was the following methods: analysis and synthesis (based on their interpretation of the articles of the "Journal" as a source on the history of technical science of the second half of the XIXth century. Followed by the generalization and systematization in connection with historical and cultural reality; biographical method (aimed at identifying the main 
milestones in the life and scientific activity of leaders and participants of scientific schools), and the principles of historicism (a principle which allows revealing the historical and cultural foundations of the technical branch of science), objectivity (this principle is mandatory in the process research of scientific achievements of scientists since it rejects the possibility of subjective judgments about the practical significance of scientific achievements of the scientist).

\section{Results and discussion.}

Examining this issue, several factors should be identified, the main of which are the following:

- The beginning of the Alexander II reign was marked by expectations of changes in the socio-political and economic life of the Russian Empire. Reforms that took place in the '60s of the XIXth century contributed to the increase in the pace of industrial modernization. In turn, the acceleration of the capitalist development of the state was inextricably linked with the development of the exact and natural sciences. They provided scientific and technological progress in the field of production and trade;

- as a result, derived from conditions of increasing rates of capitalist development, the state urgently needed personnel who would combine both scientific potentials, and would guarantee successful development of trade and industrial activity. That is why the problem of modernization of educational institutions became a foundation for vocational education. There was an urgent need to introduce new standards for this kind of education.

The large-scale transformations were impossible without in-depth research that would cover all possible issues, form a proper framework, and ensure the functioning of the entire system. A professional and scientific approach for solving new problems in the field of technical science was presented in the publications of the "Journal" in the 60-70s of the XIXth century. Therefore, the research turns to the most thorough articles that showed the rapid pace and expansion of development vectors of exact and natural sciences. It also touches upon the emergence of scientific schools in this field in Ukraine at this time.

An important scope of information on the development of science is contained in the article "Report of the Imperial Academy of Sciences on the Department of Physics, Mathematics, and History and Philology for 1860". (Otchet Imperatorskoj Akademii nauk po fiziko-matematicheskomu i istoriko-filologicheskomu otdeleniyam za 1860 god, 1861, p. 121-142). This article publishes a report that contained three works by Mykhailao Vasylovych Ostrohradskyi, entitled as: "On the curvature of surfaces", "Note on one definite integral" and "On a new presentation of the theory of largest and smallest quantities" (OIAN, 1861, pp. 135-136). The author of these articles was one of the most outstanding, world-class mathematicians and mechanics. Born in the village of Pashenivka, Poltava region, he entered Kharkiv University in 1817. After graduating from high school, he received the title of Candidate of Sciences, but unfortunately, bureaucratic conflicts did not allow him to approve him in this title. 
From 1822 he continued his studies in Paris, at the Collège de France, where at that time the brilliant scientists - Ampère, Laplace, Fourier was providing lectures. Upon his return, he was elected adjunct professor at the St. Petersburg Academy of Sciences. In 1831, he received the title of ordinary academician in applied mathematics, and later took the position of the head of the Department of Mathematics, after the death of his colleague and academician P. M. Fuss.

It is fascinating that the scientific interests of M. V. Ostrohradskyi were not limited to mathematics. He was engaged in mathematical analysis, mathematical foundations of physics, and mechanics. M. V. Ostrohradskyi was a man of Enlightenment views, who paid attention not only to scientific research but also to the dissemination of scientific knowledge. His teaching activities at the Marine Cadet Corps, the Main Engineering School, left his students with a lot of memories. Students of schools and St. Petersburg University remembered his lectures throughout their lives, they noted the scientific and unsurpassed skill to teach educational material, focusing on the latest achievements in the field of exact sciences (Tripol'skij, 1902).

The scientific school was presented by I. O. Vyshnehradskyi. After the founding of the branch of the Academic Committee for Technical and Vocational Education on January 13, 1884, the professor of the St. Petersburg Institute of Technology I. O. Vyshnehradskyi was directly in charge of the branch (Georgievskij, 1902, p. 44). In this case, it must be noted that a large number of prominent scientists became a part of this school. For instance, Ye. F. Sabinin (the first scientist at Novorossiysk University who defended his doctoral dissertation on pure mathematics), I. I. Rakhmaninov (mathematician and mechanic, doctor of mathematical sciences and Astronomy, Dean of the Faculty of Physics and Mathematics of St. Vladimir's University, who was also elected as the president of this university in the 80's), V. O. Panaiev (an engineer and creator of railways, who, incidentally, made significant efforts to scientific substantiation and technical examination of the construction of the railways in the eastern region of Ukraine. He was also in charge of building the road between Kyiv and Kursk).

In the "Report of the Imperial Academy of Sciences on the Department of Physics, Mathematics, and History and Philology for 1860" a note about the scientific works of Viktor Yakovych Buniakovskyi was found. The first report was entitled "On the special transformation of integrals", the second report touched upon the issues of planimetry and was an addition to scientific and applied value (OIAN, 1861, p. 124). It is known that V. Ya. Buniakovskyi was born in the city of Bar. An important role in the education of the young man was played by a friend of is father Earl O. P. Tormasov, who sent V. Ya. Buniakovskyi to Germany and then to Switzerland. V. Ya. Buniakovskyi also continued to obtain his mathematical education in France, where he met his mentor O. L. Koshi, who played an important role in the life of M. V. Ostrohradskyi. He also attended courses for famous mathematicians and physicists at the Collège de France. In 1825 he defended his dissertation at the Sorbonne and received a doctorate in mathematics. After moving to St. Petersburg, he became a lecturer of analytical 
mechanics at St. Petersburg University and made significant strides in solving problems related to probability theory. By following this research field, he gained worldwide recognition. In 1836 he received the title of ordinary professor, and later in 1864, he was elected vice-president of the Academy of Sciences. The scientific achievements of the scientist consist of more than 100 scientific works (Samoilenko, Melnyk, V. \& Melnyk, O., 2004).

A special place in the "Journal" is dedicated to the Order of the Minister of Education on February 26, 1877, which referred to the appointment of title "Ordinary Professor of the Imperial University of Novorossiysk, State Counselor to Shvedov Dean of the Faculty of Physics and Mathematics of this university for three years" (Prikaz ministra narodnogo prosveshheniya 26 fevralya 1877 g., № 2., 1877, p. 23). F. N. Shvedov was born in the small town of Kiliya in 1840 . He received his primary and secondary education at the 2nd Odessa Gymnasium, followed by the studies at the Richelieu Lyceum. He graduated from the Faculty of Physics and Mathematics of St. Petersburg University, where he began his scientific career under the guidance of Professor F. F. Petrushevskyi.

In 1865 F. N. Shvedov was sent to Berlin to the physical laboratory of Henrikh Hustav Mahnus. In 1868, after defending his dissertation in St. Petersburg, he received a master's degree in physics and was invited to work at Novorossiysk University. Here F. N. Shvedov began to research various areas of physical science. In his scientific work, he contributed more than fifty scientific articles on rheology (elasticity of form and viscosity of colloids), electricity, geophysics. F. N. Shvedov also studied the physics of celestial bodies (Vejnberg, 1907, p. 11-15). The scientist paid attention to technical inventions. He developed a device used in military affairs to measure distance with great accuracy, the so-called sighting rangefinder (Ergin, 2015).

It should be noted that F. N. Shvedov is considered as one of the most prominent developers of the theoretical foundations of methods in teaching physics. His work "Methods of Physics" contains the views of the scientist on new trends in the development of physics and its philosophical foundations. The scientist considered the problems of didactics, methods of teaching physics in educational institutions, and proved the need for newly structured physics textbooks (Shvedov, 1894).

"Report of the Imperial Academy of Sciences on the Department of Physics, Mathematics, and History and Philology for 1860" contains information concerning the natural sciences in Ukraine. In particular, the need to organize a paleontological museum. This proposal was made by Academicians Halmerson and Brand. They advised to conduct a detailed geological study of the southern region of Ukraine: "The compilation of such a museum ... and such knowledge could be useful for the needs of agriculture, manufacturing, in short, for technical practice" (OIAN, 1861, p. 124). At this time the Academy of Sciences received a report from Admiral Butakov on the discovery of a mastodon. In the report it was stated that "12 miles away from Nikolaev in the settlement Voskresenka (Horokhivka) quite a large fossil animal was found" (OIAN, 1861, p. 125). It was decided to send paleontological and zoological 
expeditions to this area, led by academicians Brand and Radko. The scientists found that the remains were perfectly preserved and belonged to a mastodon. Further in the report, it was emphasized that the expedition managed to collect a large number of remains of antediluvian animals found near the village of Nerubaiske. In Mykolaiv, members of the expedition paid special attention to studying the breeds of fishes found in river Bug. In the report, it was stated that "Odessa also brought several new species of this class of animals" (OIAN, 1861, p. 125).

Thus, the analysis of the articles placed in the "Journal" devoted the development of exact and natural sciences and proved the fact of their rapid development in the 60s of the XIXth century. It also underlined the fact of great public interest in the new achievements and trends in science. The above-mentioned scientists contributed to the foundation for the development of Ukrainian science in the field of mathematics, statistics, physics, astronomy, and mechanics. It should be noted that scientists were focused not only on scientific research but they also comprehended the applied value of their research, made significant efforts to disseminate scientific knowledge. It was a movement that caused the high pace of scientific and technological progress.

In connection with the above-stated facts, another question aroused. Specifically saying, the need to modernize the education system. The system that would put a focus on new ways for students to gain knowledge in mathematics, physics, science, train technical specialists, consequently providing opportunities to apply knowledge in practice. In this regard, it is necessary to consider the peculiarities of the formation of real education in the '60s of the XIX century, which sheds light on the creation of an educational base as the second component in the formation of technical science.

The first stage of reforms began with the approval of the Minister of Education O. V. Holovnin, who led the office in December 1861. It should be noted that the transformations of this time were largely aimed at creating an educational system, similar to the one that already existed for many years in Western Europe. One of the oldest real schools - Friedrich-Wilhelm, was founded by Johann Hecker in Berlin in 1747. According to accepted European practice, classical gymnasiums focused on the study of ancient languages - Latin and Greek, history, literature. They were a preparatory base for continuing education at universities. In turn, the real school curriculum had subjects as science, mathematics, anatomy, statistics, economics, and architecture. Latin and Greek were either not studied at all or taught to a lesser extent. Instead, real schools paid considerable attention to the study of so-called "new languages" - English, German, French. These educational institutions did not set the main task of preparing students for admission to universities. They contributed to the acquisition of real knowledge that would allow students to successfully apply the skills and information in their commercial and industrial activities. As a result, the students had shorter time frames of study than students in classical high schools.

The fact that children from middle-class families studied in real schools should be emphasized. Usually, those students were the descendants of entrepreneurs and traders who had to follow the family business. Alternatively, students who just wanted 
to build a career in entrepreneurship were also entering the real schools. They did not aim to gain in-depth knowledge of the classical sciences but were focused on the acquisition of applied knowledge. Shorter terms of education, the option of saving money, and the ability to avoid significantly difficult subjects, such as Latin and Greek, gaining knowledge that will be useful in the labor market - all these factors have led to the rapid development of real schools across Europe. It should be noted that on the pages of the "Journal of Public Education" the discussions on key issues of implementation of new forms of real education began before the appointment of Minister O. V. Holovnin.

Clear evidence of this is the article "Report of printed reviews of the draft charter of secondary and lower educational institutions, which were in the department of MNP" (Svod pechatnyh recenzij na proekt ustava srednih i nizshih uchebnyh zavedenij, sostoyashchih v vedomstve Ministerstva narodnogo prosveshcheniya, 1861, pp. 244-293). In the article, Robert Vasylovych Orbinskyi presented his vision of the forthcoming reforms. Meanwhile, the scientist had also considerable pedagogical experience. In 1851 he took the position of associate professor of the Odessa Richelieu Lyceum at the Department of Pedagogy. In the mid-1950s, he repeatedly participated in various commissions composed of teachers of the Richelieu Lyceum to conduct tests on the topic of home teachers and attended classes of high school teachers to monitor their activities. In the article, R. V. Orbinskyi wrote the following: "Every system of educational institutions must be consistent with the requirements of life" (SPR, 1861, p. 244).

It is known that the scientist and educator R. V. Orbinskyi disagreed with the critics of the reform project who didn't agree that students cannot continue their education at universities after graduating from a real gymnasium. R. V. Orbinskyi believed that a small amount of Greek and Latin, in real high schools would not allow students to build a university career. He paid special attention to the problem of organizing future real schools. In his opinion, the main factor in their arrangement should have been considered by the regional needs of society. He fully agreed with the fact that in the future, the charter of real schools should use the experience of countries such as Prussia and France. His article also contains opposing views on reform. Thus, the most criticized were the provisions of the charter, which closed the possibility for students of real high schools to enter universities. For example, Mr. Neverov article contains a proposal to allow realists to continue their education at the physics and mathematics faculties of universities (SPR, 1861, p. 244).

In addition to the before-mentioned facts, the data of the article "A few words about the introduction to the physics and mathematics faculties of teaching applied sciences" by I. I. Rakhmaninov should be studied. The article appeared on the pages of the "Journal" in 1863 (Rakhmaninov, 1863, pp. 350-378). At that time, the scientist held the position of ordinary professor of the Department of Applied Mathematics at St. Vladimir's University in Kyiv. He noted the fact that "applied physics, applied chemistry, practical mechanics, the science of building art entered the environment of 
abstract sciences should take an honorable place ... factories, where they contribute their knowledge, their science ... The boundary between science and the routine industry is finally destroyed (Rakhmaninov, 1863, p. 355).

Also, the scientist provides an in-depth analysis of the real education system in Western Europe. He wrote about the experience of England, considered the activities of the Royal Society of Art, which organized the first and second world exhibitions and "took an active part in the dissemination of scientific knowledge directly related to industry" (Rakhmaninov, 1863, p. 359). "In many cities, so-called mechanical institutes have been established, where physics and chemistry and mechanics are taught in the evenings (Rakhmaninov, 1863, p. 360).

In his opinion, France took a different path. "Practical education is headed by a polytechnic school ... The purpose of the polytechnic school is to prepare young people for special schools, where young people receive a final practical education that corresponds to their type of service. Those who want to enter a polytechnic school must first provide a diploma confirming the fact of general education" (Rakhmaninov, 1863, p. 364).

The significant contribution of I. I. Rakhmaninov underlined the examination system in the polytechnic school, emphasizing the following: "With such a schedule and strict definition and thoughtful programs, it was possible to introduce examiners separate from teachers" (Rakhmaninov, 1863, p. 365).

In his opinion, a system, in which exams are assessed by invited teachers, guaranteed an objective approach to knowledge assessment. He also considered the experience of Germany in teaching applied sciences. "The rapid development of industrial activity in Germany was undoubtedly influenced by schools dedicated to technical education and concentrated in all major cities of Germany under the name of polytechnics, craft institutes, construction academies" (Rakhmaninov, 1863, p. 368).

Then I. I. Rakhmaninov stated: "In my opinion, the teaching of construction art should be introduced in the faculties of physics and mathematics as an application of statics; practical mechanics as an application of dynamics; industrial physics, as an addition to the laws of general physics; technical chemistry, as an addition to the laws of general chemistry, without a doubt, to add here descriptive geometry with all its important applications, exercises in drawing, drafting"(Rakhmaninov, 1863, p. 371).

Summing up the analysis of the current state of development of real education in Western Europe, he argues that "the nature of the study of practical sciences in universities should be strictly scientific and at the same time practical" (Rakhmaninov, 1863, p. 371).

Additionally, it should be noted that as a result of the reform activities of O. V. Holovnin in November 1864 in the Russian Empire adopted a new charter on gymnasiums, which divided them into classical and real (Ustav gimnazii i progimnazij vedomstva Ministerstva narodnogo prosveshcheniya, 1876). Another feature of the charter was the fact that the choice by the institution to become either classical or real gymnasiums were chosen by local societies, taking into account regional needs. 
However, in practice, this choice was often made unreasonably. According to the statute, real gymnasiums did not give students the right to enter the university, which very soon led to a reduction in the student number, and caused further reform of the technical education system.

\section{Conclusions.}

The study of the formation components of technical science in Ukraine in the 6070 s of the XIXth century shows the following facts. Firstly, the development was made due to significant advances in scientific and technical thought and qualitative changes that have taken place in the basic sciences. During this period, the positions of Ukrainian scientists were significantly strengthened. They consistently implemented new principles and approaches in solving key issues of mathematics, physics, and natural sciences. Secondly, the use of research results began to be key in increasing the rate of the industrial revolution and the development of technological potential. Thirdly, the role of science in relation to public demand was changing. Social communication of researchers became an important characteristic of scientific activity. Scientists focused not only on solving theoretical scientific issues but also fully immersed themselves in the world of technology-oriented research. The vector of scientific developments was increasingly inclined towards the direct solution of applied scientific issues. Fourthly, new horizons in the development of science and technology necessitated radical changes in the education system. Training and providing professional and technical personnel to industrial enterprises became an urgent problem. This issue was about to be solved by the educational reforms that began in the 60s of the XIXth century. It found out that the main component of the formation of technical science in 60-70 of the XIXth century was its close connection with the advanced ideas of science and reforming the system of vocational education.

\section{References}

Ergin, Yu. V. (2015). F. N. Shvedov (1840-1905): Osnovopolozhnik teoreticheskih osnov metodiki prepodavaniya fiziki [F. N. Shvedov (1840-1905): The founder of the theoretical foundations of the teaching methods of physics]. Retrieved from https://www.eduspb.com/public/books/byograf/shvedov_fn.pdf [in Russian].

Georgievskij, A. I. (1902). K istorii Uchenogo komiteta Ministerstva narodnogo prosveshcheniya [To the history of the Scientific Committee of the Ministry of Public Education]. Zhurnal Ministerstva narodnogo prosveshheniya - Journal of the Ministry of Public Education (Vol. 341), (pp. 33-72). Sankt-Peterburg: Senatskaya tipografiya [in Russian].

Honchar, M. V. (2016). Rozvytok nyzhchoi profesiinoi osvity na Pivdni ukrainy u II polovyni XIX - pochatku XX stolittia [Development of lower professional education in the South of Ukraine in the second half of the XIX - early XX 
century]. Extended abstract of candidate's thesis. Ternopil: Vektor [in Ukrainian].

Hushchyna, S. O. (2007). Typolohiia pryvatnykh zakladiv osvity v Ukraini (XIX pochatok XX stolittya) [Typology of private educational institutions in Ukraine (XIX - early XX century)]. Visnyk Zhytomyrskoho derzhavnoho universytetu imeni Ivana Franka Zhytomyr State University, 36, 111-115 [in Ukrainian].

Likarchuk, I. L. (1999). Profesiino-tekhnichna osvita Ukrainy: istorychnyi shliakh $i$ perspektyvy [Vocational and technical education of Ukraine: historical path and prospects]. Kyiv: Pedagogika [in Ukrainian].

Otchet Imperatorskoj Akademii nauk po fiziko-matematicheskomu i istorikofilologicheskomu otdeleniyam za 1860 god. (1861). [Report of the Imperial Academy of Sciences on Physics and Mathematics and Historical and Philological Departments for 1860]. Zhurnal ministerstva narodnogo prosveshheniya Journal of the Ministry of Public Education (Vols. 109), (pp. 121-142). SanktPeterburg: Senatskaya tipografiya [in Russian].

Plavutska-Lutsenko, Ya. Yu. (2013). Rozvytok derzhavnoi systemy osvity v Rosiiskii Imperii XIX st. [Development of the state education system in the Russian Empire in the XIX century]. Teoretichni pitannya kulturi, osviti ta vikhovannya Theoretical issues of culture, education and upbringing, 48, 36-41 [in Ukrainian]. Prikaz ministra narodnogo prosveshheniya 26 fevralya 1877 g. № 2. (1877). [Order of the Minister of Public Education on February 26, 1877 No. 2]. Zhurnal Ministerstva narodnogo prosveshheniya - Journal of the Ministry of Public Education (Vols. 191), (p. 23). Sankt-Peterburg: Senatskaya tipografiya [in Russian].

Rakhmaninov, S. (1863). Neskol'ko slov o vvedenii v fiziko-matematicheskie fakul'tety prepodavaniya prikladnyh nauk [A few words about the introduction to physics and mathematics faculties of teaching applied sciences]. Zhurnal Ministerstva narodnogo prosveshheniya - Journal of the Ministry of Public Education (Vols. 118), (pp. 350-378). Sankt-Peterburg: Senatskaya tipografiya [in Russian].

Samoilenko, A. M., Melnyk, V. S., \& Melnyk, O. M. (2004). Do 200-richchia vid dnia narodzhennia akademika V. Ya. Buniakovskoho [To the 200th an niversary of the birth of Academician V. Ya. Bunyakovsky]. Ukrayinskij matematichnij zhurnalUkrainian Mathematical Journal, 56 (12), 1675-1683. Retrieved from http://dspace.nbuv.gov.ua/bitstream/handle/123456789/164849/06-

Samoilenko.pdf? sequence $=1$ [inUkrainian].

Shevchuk, H. (2011). Do istorii osvity v Naddniprianskii Ukraini u XIX - na pochatku XX stolittia [To the history of education in the Dnieper Ukraine in the nineteenth - early twentieth century]. Visnik lvivskogo Universitetu - Visnyk of Lviv University, 27, 228-237 [in Ukrainian].

Shvedov, F. N. (1894). Metodika fiziki. Vypusk 1. Vvedenie [Physicstechnique. Issue 1. Introduction]. Odessa: Central'naya tipografiya [in Russian]. 
Siropolko, S. (2001). Istoriia osvity v Ukraini [History of education in Ukraine]. Kyiv: Naukova dumka [in Ukrainian].

Svod pechatnyh recenzij na proekt ustava srednih i nizshih uchebnyh zavedenij, sostoyashchih v vedomstve Ministerstva narodnogo prosveshcheniya. (1861). [A set of printed reviews of the draft statutes of secondary and lower educational institutions under the Ministry of Public Education]. Zhurnal Ministerstva narodnogo prosveshheniya - Journal of the Ministry of Public Education (Vols. 109), (pp. 244-293). Sankt-Peterburg: Senatskaya tipografiya [in Russian].

Tovkanets, O. S. (2011). Rozvytok profesiino-tekhnichnoi osvity v Ukraini. [Development of vocational education in Ukraine]. Naukovyi visnyk Uzhhorodskoho universytetu. Seriia: Pedahohika. Sotsialna robota - Pedagogy. Social work, 23, 183-185 [in Ukrainian].

Tripol'skij, P. (1902). Mihail Vasil'evich Ostrogradskij. Prazdnovanie stoletiya dnya ego rozhdeniya Poltavskim kruzhkom lyubitelej fiziko-matematicheskih nauk [Mikhail Vasilievich Ostrogradsky. Celebration of the centenary of his birthday by the Poltava circle of lovers of physical and mathematical sciences]. Poltava: Tipo-Litografiya Torgovogo Doma «L. Frishberg» [in Russian].

Ustav gimnazii i progimnazij vedomstva Ministerstva narodnogo prosveshcheniya [Charter of gymnasiums and progymnasiums of the department of the Ministry of Public Education] (1876). Sbornik postanovlenij po Ministerstvu narodnogo prosveshcheniya. Carstvovanie imperatora Aleksandra II 1855-1864 - Collection of decrees on the Ministry of Public Education. Reign of Emperor Alexander II 1855-1864, 3, 1420-1469 [in Russian].

Vejnberg, B. P. (1907). Iz vospominanij o F. N. Shvedove [From the memoirs of F. N. Shvedov]. Zhurnal Russkogo fiziko-khimicheskogo obshhestva (fizicheskoe otdelenie) - Journal of the Russian Physicochemical Society (Physical Department), 39, 11-15 [in Russian].

\section{Віра Окорокова}

Південноукраїнський національний педагогічний університет імені К. Д. Ушинського, Україна

\section{Ольга Ліхачова}

Південноукраїнський національний педагогічний університет імені К. Д. Ушинського, Україна

\section{Складові формування технічної науки в Україні у 60-70 роки XIX століття}

Анотація. Стаття присвячена дослідженню питання формування технічної науки в Україні у другій половині ХІХ століття. Дюерельною базою роботи стали статі «Журналу міністерства народного просвітництва» 60-70 
років ХІХ століття, щзо і пояснює зазначені в темі хронологічні межі. Автори звертають увагу на формування технічної науки як складного процесу, щуо став результатом історико-культурних трансформацій в сфері наукових досліджень тодішнього українського суспільства. Парадигмальні зрушення в західноєвропейській науці, проникаючи у наукові кола украӥнського суспільного середовища, сприяли активізації науково-технічного прогресу. Зазначається, щуо останній мав великий вплив на сферу освіти яка, як показано в статті, стала однією з складових у процесі формування технічної наукової галузі. Зокрема мова йде про активну діяльність науково-технічної інтелігенції, яка стала рушійною силою в даному прочесі, щуо виразилося у створенні теоретико-методологічної основи напрямів наукової діяльності. На основі иирокого комплексу методів історичного дослідження, було розкрито фактори прогресу в даній науковій сфері, зростання наукових шкіл провідних математиків, фізиків та іниих представників технічної науки. На основі біографічного методу аналізу було розглянуто творчий шлях очільників відомих наукових шкіл (В. Я. Буняковський, I. О. Вишнеградський, М. В. Остроградський, Ф. Н. Шведов та іниі) в руслі тенденцій тодішньої української науково-технічної галузі. Вказується на значимість та неоцінений вклад науковців для подальшої мотивації, і разом $з$ цุим актуалізації їх досліджень у подальші роки. Наголошується, щзо виникнення наукових икіл та модернізація системи технічної освіти стали основними складовими у формуванні науково-технічної еліти, яка своєю активною науковою діяльність сприяла формуванню технічної науки на теоретикометодологічному рівні.

Ключові слова: Журнал міністерства народного просвітництва; наукова школа; науково-технічний прогрес; технічна наука

\section{Вера Окорокова}

Южноукраинский национальный педагогический университет

имени К. Д. Ушинского, Украина

\section{Ольга Лихачова}

Южноукраинский национальный педагогический университет имени К. Д. Ушинского, Украина

\section{Составляющие формирования технической науки в Украине в 60-70 годы XIX века}

Аннотация. Статья посвящена исследованию вопроса формирования технической науки в Украине во второй половине ХІХ века. Источниковой базой работы стали статьи «Журнала министерства народного просвещения» 60-70 годов XIX века, что и объясняет указанные в теме хронологические рамки. Авторы обращают внимание на формирование технической науки как сложного 
процуесса, который стал результатом историко-культурных трансформаций в сфере научных исследований тогдашнего украинского общества. Парадигмальные сдвиги в западноевропейской науке, проникая в научныле круги украинской общественной среды, способствовали активизачии научнотехнического прогресса. Отмечается, что последний имел большое влияние на сферу образования которая, как показано в статье, стала одной из составляющих в проиессе формирования технической научной отрасли. В частности речь идет про активную деятельность научно-технической интеллигенции, которая стала движущуей силой в данном процессе, выразившаяся в создании теоретико-методологической основы направлений научной деятельности. На основе широкого комплекса методов исторического исследования, были раскрыты факторы прогресса в данной научной сфере, рост научных школ ведущчих математиков, физиков и других представителей технической науки. На основе биографического метода анализа были рассмотрень творческий путь руководителей известных научных икол (В. Я. Буняковский, И. А. Выинеградский, М.В. Остроградский, Ф. Н. Шведов и другие) в русле тенденций тогдашней украинской научно-технической области. Указывается значимость и неоченимылй вклад ученьх для дальнейшей мотивации, и вместе с этим актуализации их исследований в последующие годы. Отмечается, что возникновение научных школ и модернизация системь технического образования стали основными составляющчими в формировании научно-технической элитьл, которая своей активной научной деятельностью способствовала формированию технической науки на теоретикометодологическом уровне.

Ключевые слова: Журнал министерства народного просвещения; научная икола; научно-технический прогресс; техническая наука

Received 01.08.2020

Received in revised form 12.11.2020

Accepted 26.11.2020 